\title{
Pengaruh Strategi Pemasaran, Pemberdayaan dan Pelatihan terhadap Produktivitas Pengrajin Kain Tapis di Kabupaten Pringsewu
}

\author{
Bunga Ayu Sucinda ${ }^{1}$, Meliyanti ${ }^{2}$, M Iqbal Arya Pramudya ${ }^{3}$, Vicky F Sanjaya ${ }^{4}$ \\ 1, 2, 3, 4 Fakultas Ekonomi dan Bisnis - UIN Raden Intan Lampung \\ Correspondence can be addressed to: iqbalpramudya16@gmail.com
}

Received: 05.12.2020

Revised: 19.12 .2020

Accepted: 28.12 .2020

ABSTRACT

The purpose of this study was to see the effect of Marketing Strategy, Empowerment and Training on the productivity of the marketing filter cloth craftsmen. The number of respondents studied was 78 people, using saturated samples. Data collection was done by distributing questionnaires. The analysis technique used is multiple linear regression. The findings in this study are Marketing Strategy, Empowerment and Training have a positive and significant effect on employee work productivity.

Keywords: Marketing Srategy, Empowerment, Training, Productivity.

\section{PENDAHULUAN}

Keberhasilan suatu perusahaan atau organisasi dalam meningkatkan produktivitas akan sangat mendukung kemampuan bersaingnya. Tuntutan kompetensi di tengah kompetisi pada akhirnya akan menjadi hal yang tidak boleh diabaikan. Berbagai faktor dapat mempengaruhi produktivitas misalnya dari SDM itu sendiri maupun dari luar seperti lingkungan kerja, sarana produksi, dan kesehatan [1]

Keberhasilan dalam meningkatkan produktivitas tersebut bisa dilakukan dengan pemberdayaan. Pemberdayaan tenaga kerja bukan hanya isu penting dalam rana sosial dan etika tapi juga dalam bidang ekonomi. Menurut UU No. 13 tahun 2003 Bab I pasal 1 ayat 2 disebutkan bahwa tenaga kerja adalah setiap orang yang mampu melakukan pekerjaan guna menghasilkan barang atau jasa baik untuk memenuhi kebutuhan sendiri maupun untuk masyarakat. Lebih khusus lagi pemberdayaan tenaga kerja memungkinkan intensivikasi dan ekstensivikasi penjualan hasil produk. Namun pada kenyataannya penelitian terhadap pemberdayaan tenaga kerja (pengrajin lokal) yang berbasis masyarakat masih sangat jarang dilakukan [2]. 
Hasil pengumpulan data menyatakan bahwa kain tapis merupakan salah satu produk yang murni kepemilikan dari suku Lampung yang pantas untuk dilestarikan melalui inovasi dan kreatifitas yang dibutuhkan pada saat ini. Gaya hidup masyarakat sekarang ini cenderung berubah, mengikuti perkembangan zaman. Sehingga kebutuhannyapun berubah, termasuk dalam memandang sebuah produk. Jika gaya hidup sudah berbeda, maka otomatis masyarakat kekinian lebih tertarik dengan produk-produk yang bisa menunjang gaya hidup mereka.

\section{TINJAUAN PUSTAKA}

\section{Pengaruh Strategi Pemasaran Terhadap Produktifitas}

Strategi pemasaran berpengaruh positif terhadap produktifitas. Strategi pemasaran menurut Mc Charty terdiri dari unsur-unsur yang terpadu yaitu, product, price, place, dan promotion yang selalu berkembang sejalan dengan gerak perusahaan dan perubahan lingkungan. Setiap perusahaan akan selalu berusaha agar produktifitas kerja dapat ditingkatkan. Dengan demikian diperlukan suatu penerapan strategi yang baik agar dapat meningktan produktifitas [3].

Strategi pemasaran word of mouth atau dari mulut ke mulut yang menyebar melalui jaringan bisnis, sosial dan masyarakat dianggap berpengaruh terhadap keputusan pembelian yang akan meningkatkan produktifitas [4].

\section{Pengaruh Pemberdayaan Terhadap Produktifitas}

Pemberdayaan memiliki pengaruh positif dan signifikan terhadap produktivitas karyawan. Pemberdayaan karyawan merupakan strategi penting bagi organisasi untuk meningkatkan kekuatan dan keterlibatan karyawan mereka dengan asumsi bahwa karyawan yang diberdayakan cenderung lebih efisien dalam menyelesaikan pekerjaan mereka [1]. Terkait dengan penelitian sebelumnya bahwa variabel pemberdayaan memberikan pengaruh yang kuat terhadap produktivitas, berarti ada kaitan antara variabel pemberdayaan dengan produktivitas [5].

Menurut penelitian Purnami dan Utama [6] menyatakan Pemberdayaan memiliki pengaruh positif dan signifikan terhadap produktivitas kerja karyawan. Hal ini menunjukan bahwa semakin baik pemberdayaan yang diberikan perusahaan terhadap karyawan maka semakin tinggi produktivitas kerja karyawan dalam perusahaan. 


\section{Pengaruh Pelatihan Terhadap Produktifitas}

Pelaksanaan program pelatihan dianggap membawa manfaat yang cukup besar bagi perusahaan, khususnya apabila dihubungkan dengan peningkatan produktivitas kerja karyawan. Perusahaan melakukan program pelatihan untuk meningkatkan kualitas kerja karyawan yang dilakukan secara bertahap terhadap karyawan yang ada di perusahaan tersebut yang nantinya akan tercapai SDM yang sesuai dengan harapan dari pelaksanaan program pelatihan [7].

Pelatihan dapat meningkatkan keterampilan tenaga kerja. Keterampilan atau kompetensi dapat meningkatkan kinerja tenaga kerja [8] sehingga produktivitas tenaga kerja akan meningkat. Hasil penelitian ini sejalan dengan penelitian yang dilakukan oleh Gumilar [9] yang mengatakan bahwa variabel pelatihan kerja berpengaruh signifikan terhadap produktivitas kerja. Hal ini berarti pendidikan dan pelatihan dapat meningkatkan produktivitas tenaga kerja.

\section{METODE PENELITIAN}

Metode yang digunakan dalam menyusun penelitian ini adalah dengan menggunakan metode kuesioner. Target populasi dari penelitian ini adalah anak-anak muda atau millennial khususnya yang ada di daerah lampung karena isi dari kuisioner ini mengenai "pengaruh strategi pemasaran, pemberdayaan dan pelatihan terhadap produktifitas pengrajin kain tapis" yang peduli dengan kain khas lampung yaitu kain tapis lampung. Jumlah sampel atau yang mengisi kuesioner dalam penelitian ini adalah 78 responden. Penentuan jumlah sampel tersebut mengikuti kaidah tidak kurang dari lima kali jumlah indikator pengukuran variabel [10]. Selanjutnya penarikan sampel menggunakan metode simple random sampling agar asumsi SEM terpenuhi [10].

Uji validitas instrument penelitian menggunakan convergent validity dengan melihat nilai masing-masing indicator faktor loading pada item kuesioner [11]. Pengujian reliabilitas dengan melihat nilai cronbach's alpha minimal 0,6 [11]. Pengujian hipotesis dilakukan dengan analisis SEM (Structural Equation Modelling) menggunakan Smart PLS 3.

\section{HASIL DAN PEMBAHASAN}

\section{Uji Validitas dan Reliabilitas Instrumen}

Berdasarkan hasil dari uji yang telah dilakukan mendapatkan hasil yaitu, beberapa item kuisioner yang gugur karena tidak memenuhi standar faktor loading. Pada konstruk strategi pemasaran (SP) sisa 2 dari 7 pernyataan yang ada dan konstruk pemberdayaan (PMD) 
sisa 3 dari 4 pernyataan, konstruk pelatihan (PL) sisa 3 dari 4 pernyataan sedangkan pada konstruk produktivitas (PRD) tidak ada yang gugur. Selanjtunya dilakukan pengujian ulang terhadap validitas didapatkan semua nilai dari indikator berada di atas standar nilai faktor loading yaitu lebih dari atau di atas 0,6 sehingga dikatakan valid [11].

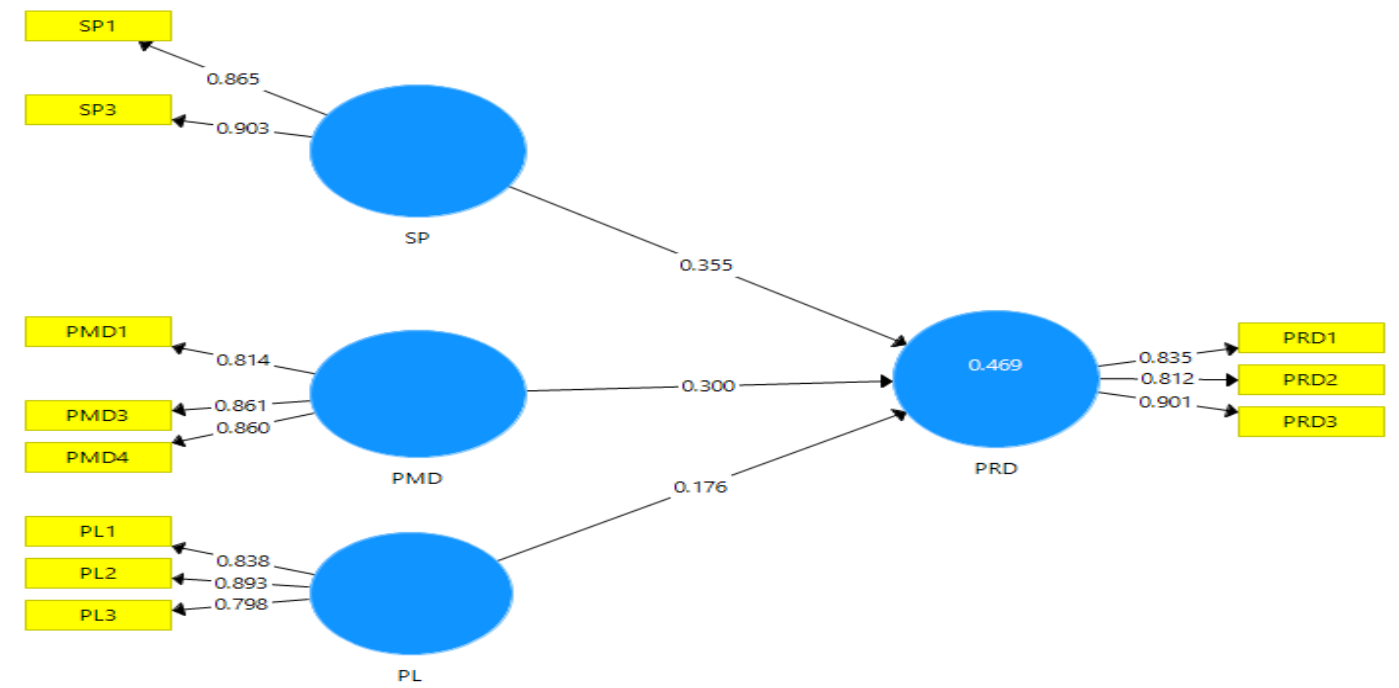

Gambar 1. Uji Validitas dan Reliabilitas Instrumen Penelitian

Keterangan:

SP : StrategiPemasaran

PMD : Pemberdayaan

PL : Pelatihan

PRD : Produktivitas

Tabel 1. Hasil Uji Validitas

\begin{tabular}{lllll}
\hline \multicolumn{1}{c}{ ITEM } & PL & PMD & PRD & SP \\
\hline PL1 & 0.838 & & & \\
PL2 & 0.893 & 0.814 & & \\
PMD1 & & 0.861 & & \\
PMD3 & 0.860 & & \\
PMD4 & & 0.835 & \\
PRD1 & & 0.812 & \\
PRD2 & & 0.901 & \\
PRD3 & & & 0.865 \\
SP1 & & & 0.903 \\
SP3 & & & & \\
\hline
\end{tabular}

Tabel 2. Hasil Uji Reliabilitas 


\begin{tabular}{lcccc}
\hline ITEM & Cronbach's Alpha & rho_A & Reliabilitas komposit & AVE \\
\hline PL & 0.801 & 0.840 & 0.881 & 0.713 \\
PMD & 0.804 & 0.828 & 0.882 & 0.715 \\
PRD & 0.809 & 0.829 & 0.887 & 0.723 \\
SP & 0.723 & 0.735 & 0.878 & 0.782 \\
\hline
\end{tabular}

\section{Uji Hipotesis}

Hipotesis 1: Strategi pemasaran berpengaruh positif terhadap produktifitas karyawan Hipotesis menunjukkan bahwa strategi pemasaran berpengaruh positif dan signifikan terhadap kinerja pemasaran dengan nilai $(0.269<0.05)$. Setiap perusahaan akan selalu berusaha agar produktifitas kerja dapat ditingkatkan. Dengan demikian diperlukan suatu penerapan strategi yg baik agar dapat meningkatkan produktifitas [3].

Hipotesis 2: Pemberdayaan memiliki pengaruh positif dan signifikan terhadap produktifitas kerja karyawan

Hasil uji menunjukan bahwa pemberdayaan berpengaruh terhadap produktifitas dengan nilai P- value $(0.065<0.05)$ didukung oleh penelitian terdahulu oleh Purnami \& Utama [6] menyatakan Pemberdayaan memiliki pengaruh positif dan signifikan terhadap produktivitas kerja karyawan. Hal ini menunjukan bahwa semakin baik pemberdayaan yang diberikan perusahaan terhadap karyawan maka semakin tinggi produktivitas kerja karyawan dalam perusahaan.

Hipotesis 3: Pelatihan berpengaruh positif terhadap produktifitas kerja karyawan Berdasarkan pengujian yang telah dilakukan menyatakan bahwa pelatihan berpengaruh positif terhadap produktifitas dengan nilai P-value $(0.024<0.05)$. Hal ini sejalan dengan penelitian yang dilakukan oleh Gumilar [9] mengatakan bahwa variabel pelatihan kerja berpengaruh signifikan terhadap produktivitas kerja. Hal ini berarti pendidikan dan pelatihan dapat meningkatkan produktivitas tenaga kerja. Semakin sering pelatihan diadakan, maka semakin tinggi produktivitas kerja karyawan.

\section{KESIMPULAN DAN SARAN}

\section{Kesimpulan}

Berdasarkan hasil pengujian yg telah dilakukan di atas, dapat disimpulkan bahwa strategi pemasaran berpengaruh positif terhadap produktifitas. Strategi pemasaran menurut Mc Charty terdiri dari unsur-unsur yang terpadu yaitu, product, price, place, dan promotion 
yang selalu berkembang sejalan dengan gerak perusahaan dan perubahan lingkungan. Hal yg sama dengan pengaruh pemberdayaan memiliki pengaruh positif dan signifikan terhadap produktivitas karyawan. Pemberdayaan karyawan merupakan strategi penting bagi organisasi untuk meningkatkan kekuatan dan keterlibatan karyawan mereka dengan asumsi bahwa karyawan yang diberdayakan cenderung lebih efisien dalam menyelesaikan pekerjaan mereka. Begitu pula dengan Pelatihan berpengaruh positif terhadap produktifitas kerja karyawan Pelaksanaan program pelatihan dianggap membawa manfaat yang cukup besar bagi perusahaan, khususnya apabila dihubungkan dengan peningkatan produktivitas kerja karyawan. Perusahaan melakukan program pelatihan untuk meningkatkan kualitas kerja karyawan yang dilakukan secara bertahap terhadap karyawan yang ada di perusahaan tersebut yang nantinya akan tercapai SDM yang sesuai dengan harapan dari pelaksanaan program pelatihan.

\section{Saran}

Pelatihan yang sesuai dengan kebutuhan kerja saat ini, mengingat persaingan yang semakin tinggi. Penelitian selanjutnya dapat mencangkup ruang lingkup sektor jasa yang lebih luas dan mungkin menambah variabel moderating seperti tingkat pendidikan, ukuran organisasi, aspek penghargaan dan aspek lainnya. Hal tersebut memungkinkan untuk mengidentifikasi aspek kunci lain yang harus dipertimbangkan dalam merancang strategi sumber daya manusia yang efektif untuk meningkatkan produktivitas karyawan dan daya saing perusahaan.

\section{UCAPAN TERIMA KASIH}

Alhamdulillah puji syukur kehadirat Allah swt, karena kehendak dan ridha-Nya peneliti dapat menyelesaikan artikel ini. Kami sadari jurnal ini tidak akan selesai tanpa doa, dukungan dari berbagai pihak. Adapun dalam kesempatan ini kami ingin mengucapkan banyak terimakasih kepada semua pihak yang telah membantu selesainya artikel ini.

\section{REFERENSI}

[1] I. M. A. Prabawa and I. W. G. Supartha, "Meningkatkan Produktivitas Karyawan Melalui Pemberdayaan, Kerja Sama Tim dan Pelatihan di Perusahaan Jasa," E-Jurnal Manaj. Univ. Udayana, vol. 7, no. 1, p. 497, 2017, doi: 10.24843/ejmunud.2018.v7.i01.p19.

[2] B. S. Pasar, S. Spasial, E. G. Tangkere, A. Julia, and M. Maweikere, "Sistem Pemasaran Optimal Meubel Kayu Kelapa,” vol. 5, no. September, pp. 90-99, 2018.

[3] I. Setiawati, "Pengaruh Strategi Pemasaran Online Terhadap Peningkatan Laba 
Umkm," Strateg. Komun. Pemasar, no. 20, pp. 1-5, 2017, [Online]. Available: file:///C:/Users/BAYU/Downloads/Documents/263-760-1-PB.pdf.

[4] A. Rembon, L. Mananeke, and E. Gunawan, "Pengaruh Word of Mouth dan Kualitas Produk Terhadap Keputusan Pembelian pada PT. Kangzen Kenko Indonesia di Manado," J. EMBA J. Ris. Ekon. Manajemen, Bisnis dan Akunt., vol. 5, no. 3, 2018.

[5] A. Arifin, H. Djamhur, and M. S. Hakam, "Pengaruh Pemberdayaan dan Motivasi terhadap Kinerja Karyawan (Studi pada Karyawan CV. Catur Perkasa Manunggal)," J. Adm. Bisnis S1 Univ. Brawijaya, vol. 8, no. 2, p. 79932, 2014.

[6] N. M. I. Purnami and I. W. M. Utama, "Pengaruh Pemberdayaan, Motivasi Dan Lingkungan Kerja Terhadap Produktivitas Kerja Karyawan," E-Jurnal Manaj. Univ. Udayana, vol. 8, no. 9, p. 5611, 2019, doi: 10.24843/ejmunud.2019.v08.i09.p13.

[7] S. Wahyuningsih, "Pengaruh Pelatihan Dalam Meningkatkan Produktivitas Kerja Karyawan,” J. War. Ed., vol. 60, no. April, pp. 91-96, 2019.

[8] A. Agustina, D. Z. Hamidi, and S. Prakoso, "Pengaruh Kompetensi dan Motivasi Terhadap Kinerja Karyawan pada Perum Perhutani KPH Sukabumi," Ekonomak, vol. 5, no. 2, pp. 91-100, 2019.

[9] G. Gumilar, "Pengaruh Pelatihan Terhadap Peningkatan Produktivitas Kerja Karyawan Pada PT. Raya Sugarindo Inti Tasikmalaya," J. Ilm. Manaj. dan Bisnis, vol. 19, no. 1, pp. 55-63, 2018, doi: 10.30596/jimb.v19i1.1804.

[10] J. F. Hair, W. C. Black, B. J. Babin, and R. E. Anderson, Multivariate Data Analysis Seventh Edition. 2014.

[11] I. Ghozali, Model Persamaan Struktural. Konsep dan Aplikasi Dengan Program AMOS 24.0. Update Bayesian SEM. Semarang, 2017. 